\title{
Average Female Live Fetal Weight
}

National Cancer Institute

\section{Source}

National Cancer Institute. Average Female Live Fetal Weight. NCI Thesaurus. Code C124628.

A measurement of the average weight of all live female fetuses. 